\title{
PENGARUH HARGA BAHAN PANGAN TERHADAP INFLASI DI INDONESIA
}

\author{
Octaviana Helbawanti ${ }^{1}$, Wahyu Adhi Saputro2), Amalia Nadifta Ulfa ${ }^{3)}$ \\ 1) Fakultas Pertanian, Jurusan Agribisnis, Universitas Siliwangi, Jl. Siliwangi No 24 Tasikmalaya, Telp \\ (0265) 330634, email:octaviana@unsil.ac.id \\ 2) Fakultas Pertanian, Jurusan Agribisnis, Universitas Duta Bangsa, Alamat Universitas, \\ email:wahyuadhi@udb.ac.id \\ 2) Fakultas Pertanian, Jurusan Agribisnis, Universitas Sebelas Maret, JI. Ir. Sutami No.36 Kota \\ Surakarta, Telp. (0271) 646994,email:amalia.nadifta@staff.uns.ac.id
}

\begin{abstract}
Abstrak
Penelitian bertujuan untuk menganalisis pengaruh harga bahan pangan terhadap perkembangan inflasi di Indonesia. Inflasi Indonesia menunjukkan pola yang menurun pada tahun 2017 sampai 2021. Analisis pengaruh harga bahan pangan terhadap perkembangan inflasi diperlukan untuk mengevaluasi perubahan harga bahan pangan penyebab dan kontribusinya terhadap inflasi. Harga bahan pangan berfluktuasi di tengah kondisi pandemi Covid-19 pada tahun 2020 sampai 2021 karena pembatasan wilayah dan mobilitas dapat mempengaruhi proses distribusi dan ketersediaan bahan pangan. Konsumsi bahan pangan memiliki proporsi yang cukup besar dari total konsumsi rumah tangga di negara berkembang, sehingga perubahan harga pangan akan berdampak pada kondisi perekonomian melalui mekanisme permintaan dan penawaran. Metode analisis yang digunakan yaitu regresi linier berganda. Data yang digunakan dalam analisis regresi linier berganda merupakan data sekunder harga bahan pangan yaitu harga beras, daging ayam, daging sapi, telur ayam, bawang merah, bawang putih, cabai merah, cabai rawit, minyak goreng, gula pasir dan inflasi periode Juli 2017 sampai Juli 2021. Hasil analisis menunjukkan bahan pangan bawang merah, beras, daging sapi, dan minyak goreng memberikan pengaruh siginifikan dengan arah koefisien negatif pada inflasi yaitu cenderung terjadi deflasi pada pergerakan harga bahan pangan. Bawang putih, daging ayam, dan gula pasir memberikan berpengaruh positif pada peningkatan inflasi.
\end{abstract}

Kata kunci: Harga, Inflasi, Pangan

\section{Abstract}

This study aimed to analyze the effect of food prices on the development of inflation in Indonesia. Indonesia's inflation showed a declining pattern in 2017 to 2021. An analysis of the effect of food prices on inflation is needed to evaluate changes in food prices that cause and contribute to inflation. Food prices fluctuate in the midst of the Covid-19 pandemic in 2020 to 2021 because regional restrictions and mobility can affect the distribution process and availability of food ingredients. Food consumption had a fairly large proportion of total household consumption in developing countries, so changes in food prices would have an impact on economic conditions through demand and supply mechanisms. The analytical method used was multiple linear regression. The data used in the multiple linear regression analysis was secondary data consisting of food prices, namely rice, chicken meat, beef, chicken eggs, shallots, garlic, red chilies, cayenne pepper, cooking oil, granulated sugar and inflation for the July period. 2017 to July 2021. The results of the analysis explained that food ingredients shallots, rice, beef, and cooking oil had a significant effect with a negative coefficient direction on inflation, namely deflation tends to occur in food price movements. Garlic, chicken meat, and sugar had a positive effect on increasing inflation.

Keywords: Price, Inflation, Commodity 
Agrisaintifika

Jurnal Ilmu-Ilmu Pertanian

Vol. 5, No. 2, 2021

Helbawanti, et al. 2021

\section{PENDAHULUAN}

Ketergantungan yang besar terhadap sektor pertanian masih tinggi untuk mewujudkan kesejahteraan masyarakat terutama pada tanaman pangan yang dikendalikan melalui penetapan harga dasar dan harga tertinggi bahan pangan. Pemerintah berperan untuk menjaga kestabilan harga produk pertanian baik pada saat terjadi over produksi maupun saat terjadi masa kegagalan panen sehingga tidak akan terjadi gejolak harga produk pertanian yang dapat memberikan dampak buruk pada kestabilan harga-harga barang dan jasa pada umumnya (Boediono, 2005) Inflasi sangat berpengaruh terhadap perekonomian suatu negara. Inflasi menggambarkan daya beli suatu nilai tukar dalam suatu periode. Daya beli yang terus menurun dapat mengindikasikan terjadinya peningkatan inflasi karena ketidakmampuan menjangkau harga yang terus mengalami kenaikan. Pembelian suatu barang menjadi lebih sedikit kuantitas yang diperoleh dibanding periode sebelumnya dengan harga yang sama.

Inflasi dapat digunakan sebagai indikator kondisi perekonomian yang dapat diartikan positif dan negatif. Nilai suatu aset dapat tergantung pada perkembangan inflasi. Inflasi dapat dikategorikan menjadi tiga tipe yaitu demand-pull inflation, cost-pull inflation, dan built-in inflation. Badan Pusat Statistik (BPS) mengukur inflasi pada barang dan jasa yang dikonsumsi yaitu bahan makanan; makanan jadi, minuman, rokok, dan tembakau; perumahan, air, listrik, gas, dan bahan bakar; sandang; kesehatan; pendidikan, rekreasi, dan olahraga; transportasi, komunikasi, dan jasa keuangan; dan umum. Perubahan harga barang dan jasa dapat berdampak pada kondisi perekonomian, termasuk perubahan bahan pangan pokok. Kenaikan harga bahan pangan dapat berkontribusi terhadap inflasi suatu negara (Al-Shawarby \& Selim, 2013). Menurut (Widiarsih, 2012), harga beras berpengaruh signifikan terhadap Inflasi bahan makanan baik dalam jangka panjang maupun jangka pendek yang ditandai dengan nilai koefisien regresi yang bertanda positif. Demikian pula dengan beberapa komoditas pangan lainnya. Menurut penelitian (Darma et al., 2018)menyatakan bahwa harga komoditas beras, bawang merah dan cabai merah berpengaruh positif signifikan terhadap tingkat inflasi di Indonesia. Harga komoditas cabai merah merupakan variabel yang berpengaruh dominan terhadap tingkat inflasi di Indonesia. Bahan pangan pokok dapat diklasifikasikan sebagai volatile food yaitu terdiri dari beras, daging ayam, daging sapi, telur ayam, bawang merah, bawang putih, cabai merah, cabai rawit, minyak goreng, gula pasir. (Mija et al., 2013), respon kenaikan inflasi inti akibat kenaikan harga bahan pangan di negara berkembang lebih besar dibanding negara maju karena proporsi pembelian bahan pangan di negara berkembang lebih banyak. Terdapat hubungan antara harga di tingkat produsen jika menggunakan input yang diimpor dengan tingkat inflasi (Auer \& Mehrotra, 2014).

Kebijakan moneter dapat berperan dalam pergerakan inflasi melalui pengaturan suku bunga yang berdampak pada agregat permintaan (Bhattacharya \& Jain, 2019; Holtemöller \& Mallick, 2016). Berdasarkan (Iddrisu \& Alagidede, 2020), biaya transportasi dapat mempengaruhi harga pangan dalam hal biaya produksi. Sejalan dengan penelitian (Bhattacharya \& Sen Gupta, 2017), kenaikan harga pangan berdampak pada inflasi secara agregat dan inflasi barang non-pangan melalui biaya tenaga kerja, substitusi bahan yang lebih tinggi harganya, dan pendapatan relatif produsen. Dalam (Bandara, 2013) menyatakan bahwa kenaikan harga dan permintaan bahan pangan mengandung protein dan vitamin yang tinggi serta kegagalan sistem distribusi merupakan penyebab inflasi.

Penduduk Indonesia menurut (BPS, 2021), yang mencapai 272.229.372 jiwa, jika dibandingkan dengan ketersediaan bahan pangan yang dibutuhkan seringkali tidak sesuai antara permintaan dan penawarannya. Hal ini 
dapat disebabkan karena permintaan yang melebihi jumlah produksi, kegagalan panen, hambatan distribusi, permasalahan impor, sehingga mempengaruhi fluktuasi harga bahan pangan. Harga bahan pangan merupakan salah satu faktor yang berkontribusi pada perkembangan inflasi nasional. Inflasi penting untuk diteliti karena merupakan indikator makro yang menggambarkan kondisi perekonomian suatu negara. Penelitian ini bertujuan menganalisis pengaruh harga bahan pangan pokok yang terdiri beras, daging ayam, daging sapi, telur ayam, bawang merah, bawang putih, cabai merah, cabai rawit, minyak goreng, gula pasir terhadap inflasi, sehingga dapat diketahui faktor yang dapat dipertimbangkan untuk dikendalikan. Analisis dilakukan sampai periode Juli 2021 di mana Indonesia masih mengalami pandemi Covid-19, sehingga dapat dianalisis kondisi perekonomian menggunakan indikator inflasi melalui pergerakan harga bahan pangan.

\section{METODE}

\subsection{Analisis Regresi Berganda}

Data yang digunakan dalam analisis regresi linier berganda merupakan data sekunder yang terdiri dari harga bahan pangan yaitu beras, daging ayam, daging sapi, telur ayam, bawang merah, bawang putih, cabai merah, cabai rawit, minyak goreng, gula pasir dan inflasi. Satuan harga pangan adalah Rupiah per kilogram, sedangkan inflasi dinyatakan dalam persen. Sumber data diperoleh dari Pusat Informasi Harga Pangan Strategis Nasional dan Bank Indonesia dengan rentang waktu Juli 2017 sampai Juli 2021. Analisis data menggunakan perangkat lunak eviews 8.0.

Regresi linier berganda merupakan metode analisis untuk mengestimasi hubungan antara variabel bebas yang jumlahnya lebih dari satu $(\mathrm{X})$ dan variabel terikat $(\mathrm{Y})$. Model regresi linier berganda adalah sebagai berikut:

$$
\begin{gathered}
Y_{i}=\beta_{0}+\beta_{1} X_{1 i}+\beta_{2} X_{2 i}+\cdots+\beta_{p} X_{p i}+e_{i} \\
Y=X \beta+e
\end{gathered}
$$

$$
\begin{aligned}
& Y=\left[\begin{array}{c}
Y_{1} \\
\vdots \\
Y_{p}
\end{array}\right] \\
& n \times 1 \\
& n x(p+1) \\
& \beta=\left[\begin{array}{c}
\beta_{0} \\
\beta_{1} \\
\vdots \\
\beta_{p}
\end{array}\right] \\
& e=\left[\begin{array}{c}
e_{1} \\
\vdots \\
e_{n}
\end{array}\right] \\
& (p+1) x 1 \\
& n \times 1
\end{aligned}
$$

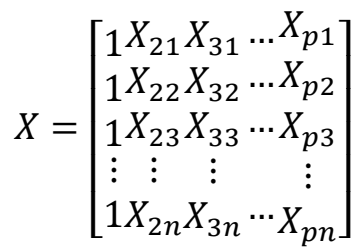

maka model regresi linier berganda pada analisis harga bahan pangan terhadap inflasi yaitu:

$$
\begin{aligned}
Y=\beta_{0}+\beta_{1} X_{1} & +\beta_{2} X_{2}+\beta_{3} X_{3}+\beta_{4} X_{4}+\beta_{5} X_{5} \\
& +\beta_{6} X_{6}+\beta_{7} X_{7}+\beta_{8} X_{8}+\beta_{9} X_{9} \\
& +\beta_{10} X_{10}+e_{i}
\end{aligned}
$$

Keterangan:

$\begin{array}{cll}Y & : \text { Inflasi } \\ \beta_{0} & : \text { Konstanta } \\ \beta_{1}-\beta_{10} & : \text { Koefisien regresi variabel bebas } \\ X_{1} & : \text { Beras } \\ X_{2} & : \text { daging ayam } \\ X_{3} & : \text { daging sapi } \\ X_{4} & : \text { telur ayam } \\ X_{5} & : \text { bawang merah } \\ X_{6} & : \text { bawang putih } \\ X_{7} & : \text { cabai merah } \\ X_{8} & : \text { cabai rawit } \\ X_{9} & : \text { minyak goreng } \\ X_{10} & : \text { gula pasir } \\ e_{i} & : \text { residu } \\ p_{3} & \end{array}$

Uji parsial

$$
t=\frac{\hat{\beta}_{j}-\beta_{j}}{\operatorname{se}\left(\hat{\beta}_{j}\right)}=\frac{\hat{\beta}_{j}}{\operatorname{se}\left(\hat{\beta}_{j}\right)}
$$

hipotesis uji parsial:

$H_{0}: \beta_{j}=0$

$H_{1}: \beta_{j} \neq 0$

$H_{0}$ ditolak jika nilai t hitung lebih kecil dari t tabel maka tidak terdapat pengaruh variabel tidak terikat terhadap variabel terikat secara individu. $H_{1}$ diterima jika nilai $t$ hitung lebih besar dari $t$ tabel, sehingga terdapat pengaruh variabel tidak terikat terhadap variabel terikat secara individu. 


\subsection{Uji Asumsi Klasik}

Pengujian asumsi klasik dilakukan agar estimasi memenuhi kriteria best, linear, dan unbiased atau BLUE. Jenis asumsi klasik terdiri dari uji normalitas, uji multikolinearitas, uji heterokedastisitas, dan uji autokorelasi.

\subsubsection{Uji Normalitas}

Uji normalitas digunakan untuk mengetahui persebaran data yang akan dianalisis. Model regresi yang baik memiliki nilai residual yang terdistribusi normal. Penentuan skor uji statistik normalitas yaitu dengan rumus chi kuadrat :

$$
X_{\text {hitung }}^{2}=\sum\left(\frac{\left(O_{i}-E_{i}\right)^{2}}{E_{i}}\right)
$$

keterangan:

$$
\begin{array}{ll}
X_{\text {hitung }}^{2} & : \text { nilai chi kuadrat hitung } \\
O_{i} & : \text { frekuensi pengamatan } \\
E_{i} & : \text { frekuensi teoritis }
\end{array}
$$$$
\text { dengan penentuan taraf nyata atau alpha yaitu: }
$$

$$
X_{\text {tabel }}^{2}=X_{(1-\alpha)(d k)}^{2}
$$

maka kriteria pengujian hipotesis uji normalitas:

$H_{0}$ : sebaran data normal

$H_{1}$ : sebaran data tidak normal

$H_{0}$ ditolak jika $X_{\text {hitung }}^{2}<X_{\text {tabel }}^{2}$

$H_{0}$ diterima jika $X_{\text {hitung }}^{2} \geq X_{\text {tabel }}^{2}$

\subsubsection{Uji Heterokedastisitas}

Uji heterokedastisitas untuk menunjukkan varian dari residu dalam kondisi homokedastisitas atau tidak. Homokedastisitas merupakan varian residu variabel bebas yang tetap sama menurut asumsi:

$$
r_{s}=1-6\left[\frac{\sum d_{i}^{2}}{n\left(n^{2}-1\right)}\right]
$$

Keterangan:

$$
\begin{array}{ccc}
r_{s}: & \text { korelasi rank spearman } \\
d_{i}: & \text { rank variabel dependen } \\
& \text { dikurangi rank variabel } \\
& \text { independen ke-i } \\
\mathrm{N} \quad: & \text { ranked individu }
\end{array}
$$

hipotesis uji heterokedastisitas dilihat dari nilai signifikansi alpha.

$H_{0}$ : homokedastisitas

$H_{1}$ : terdapat heterokedastisitas

\subsubsection{Uji Autokorelasi}

Uji autokorelasi merupakan uji untuk pola sebaran residu dalam periode waktu membentuk pola atau tidak. Jika tidak membentuk suatu pola tertentu maka tidak terdapat autokorelasi antar residu. Uji statistik menggunakan Breusch-Godfrey Serial Correlation LM Test untuk melihat korelasi residu pada periode $t$ dengan residu periode $\mathrm{t}-1$ (Breusch \& Pagan, 1980). Formula Breusch-Godfrey LM Test adalah:

$$
e_{t}=X_{t} \gamma+\left(\sum_{\varepsilon=1}^{k} \alpha_{\varepsilon} e_{t-\varepsilon}\right)+V_{t}
$$

hipotesis uji serial correlation pada residual yaitu:

$H_{0}$ : tidak terdapat serial correlation

$H_{1}$ :terdapat serial correlation

\subsubsection{Uji Multikolinearitas}

Uji multikolinearitas merupakan ujikorelasi antara variabel-variabel bebas yang dianalisis. Korelasi yang tinggi antara variabel terikat dan variabel bebas dapat menyebabkan bias dalam estimasi. Uji multikolinaeritas merupakan uji yang penting diterapkan pada estimasi yang menggunakan lebih dari satu variabel bebas. Variance inflation Factor (VIF) dapat digunakan untuk menilai tingkat korelasi.

$$
\begin{aligned}
& V I F=\frac{1}{1-R_{j}^{2}} ; j=1,2, \ldots k \\
& \text { VIF : Kolinearitas } \\
& k \quad: \text { banyaknya variabel bebas } \\
& R_{j}^{2} \quad: \text { koefisien determinasi } \\
& \text { Hipotesis pada uji multikolinearitas adalah } \\
& \text { sebagai berikut: } \\
& H_{0} \text { : tidak terdapat multikolinearitas } \\
& H_{1} \text { : terdapat multikolinearitas } \\
& \text { Jika nilai } \mathrm{VIF}<10 \text { maka hipotesis null atau } \mathrm{H} 0
\end{aligned}
$$

\section{HASIL DAN PEMBAHASAN}

Secara umum, berdasarkan (Kementerian PPN/Bappenas, 2020), inflasi akhir tahun 2020 cenderung rendah disebabkan rendahnya inflasi inti, inflasi harga bergejolak dan harga yang diatur pemerintah. Pada masa pandemi 


\section{Agrisaintifika}

Jurnal Ilmu-Ilmu Pertanian

Vol. 5, No. 2, 2021

Helbawanti, et al. 2021

permintaan konsumen turun karena penurunan pendapatan di sektor non formal dan cenderung menabung di tengah kondisi ketidakpastian. Inflasi harga bergejolak yaitu volatile foods dengan harga yang rendah akibat daya beli masyarakat menurun. Pengendalian inflasi mempertimbangkan ekspektasi inflasi, permintaan domestik, kestabilan nilai tukar dan dan harga komoditi di tingkat pasar internasional. Dalam kurun waktu 5 tahun terakhir, Indonesia mengalami perlambatan inflasi inti karena daya beli yang menurun dan sisi permintaan yang lemah. Supply jumlah uang beredar akhir tahun 2020 yaitu 44,7\% lebih tinggi dari tahun lalu yaitu $38,8 \%$ dari PDB. Jumlah uang beredar tinggi tersebut, tetapi kecepatan uang berpindah tangan (money velocity) yang terus melambat maka inflasi juga cenderung rendah (BPS, 2021). Tingkat konsumsi yang rendah dapat dilihat dari sektor keuangan perbankan yang tidak ekspansif terutama pada masa pandemi sejak tahun 2020 karena dana cenderung mengendap pada tabungan.

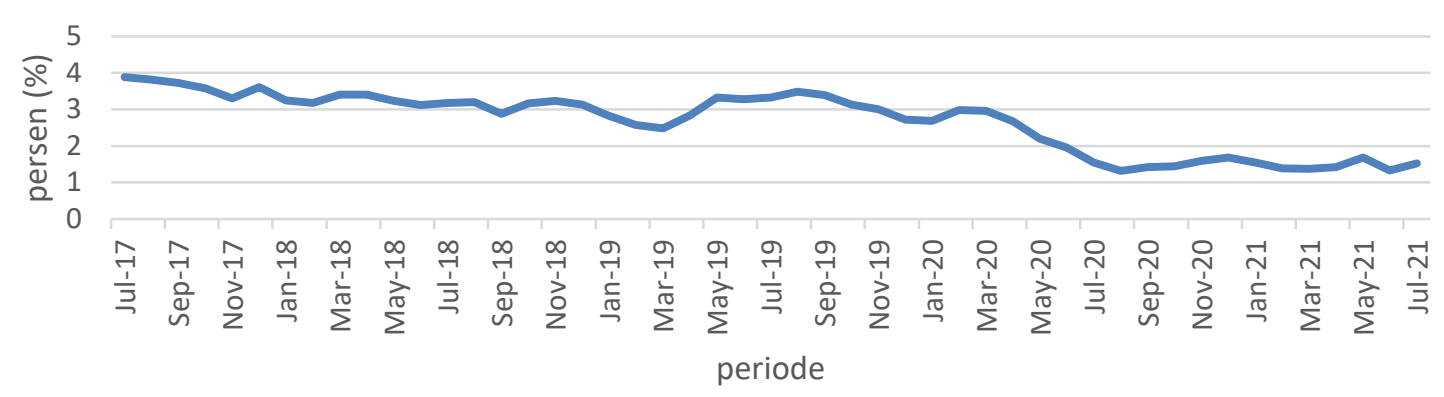

Gambar 1. Inflasi Bulanan Indonesia Juli 2017-Juli 2021

Sumber : Badan Pusat Statistik (BPS)

Berdasarkan Gambar 2. bahan pangan yang terdiri dari beras, telur ayam, dan minyak goreng cenderung mengalami kenaikan karena pada tahun 2021 harga bahan pangan tersebut tidak kembali ke harga semula di tahun 2017. Bahan pangan daging ayam, bawang merah, bawang putih, cabe merah, dan cabe rawit bergerak fluktuatif. Bahan pangan tersebut mengalami perubahan dari tahun 2017 sampai tahun 2021 dan cenderung tidak kembali pada harga terendahnya selama periode 2017-2021.

Bahan pangan yang memiliki skewness negatif adalah beras dan telur ayam. Skewness negatif menunjukkan sebaran data bahan pangan beras dan telur ayam condong mengarah ke kiri. Nilai skewness inflasi juga menunjukkan tanda negatif maka variabel inflasi memiliki kecondongan ke arah kiri atau kondisi nilai mean di sebelah kiri modus. Nilai skewness bahan pangan bawang merah, bawang putih, minyak goreng, cabai merah, cabai rawit, daging ayam, daging sapi, dan gula pasir bertanda positif artinya kecondongan data mengarah ke kanan. Kurtosis merupakan keruncingan distribusi data. Nilai kurtosis semua variabel terikat dan bebas positif maka cenderung runcing atau mengelompok homogen. Hal ini ditunjukkan dari rentang harga bahan pangan yang tidak terlalu jauh dan dalam bentuk periode bulanan. Harga tertinggi yaitu daging sapi Rp125.450,00 per kg, sedangkan harga terendah yaitu minyak goreng pada Rp13.050,00 per kg. Skewness dan Kurtosis dapat dilihat pada Tabel 1. 


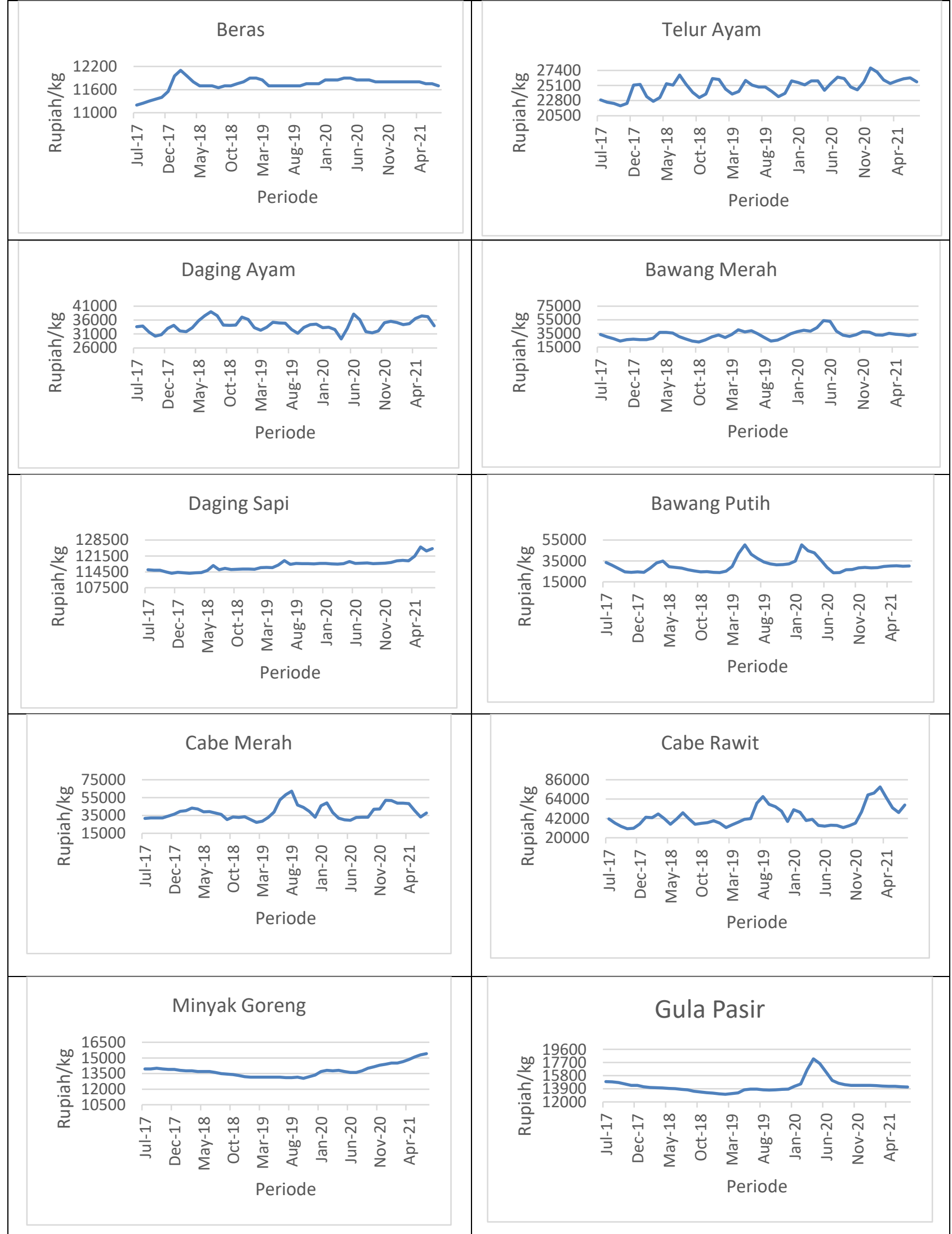

Gambar 2. Pergerakan Harga Bahan Pangan Bulanan Juli 2017-Juli 2021 Sumber : Pusat Informasi Harga Pangan Strategis Nasional 
Agrisaintifika

Jurnal Ilmu-Ilmu Pertanian

Vol. 5, No. 2, 2021

Helbawanti, et al. 2021

Tabel 1. Deskriptif Statistik Variabel Harga Pangan dan Inflasi

\begin{tabular}{|c|c|c|c|c|c|c|c|c|c|}
\hline Bahan Pangan & Mean & Median & Max. & Min. & Std.Dev. & Skewness & Kurtosis & $\begin{array}{c}\text { Jarque- } \\
\text { Bera }\end{array}$ & Prob. \\
\hline Beras & 11737.76 & 11750 & 12100 & 11200 & 176.64 & -1.390768 & 5.225659 & 27.98761 & 0.000001 \\
\hline Bawang Merah & 32788.78 & 32800 & 53550 & 22400 & 6575.51 & 1.00553 & 4.724561 & 1.048348 & 0.592044 \\
\hline Bawang Putih & 30877.55 & 29550 & 50450 & 23600 & 6571.36 & 1.401365 & 4.608986 & 7.765191 & 0.020597 \\
\hline Minyak Goreng & 13779.59 & 13700 & 15400 & 13050 & 584.69 & 1.021578 & 3.660466 & 7.341248 & 0.025461 \\
\hline Telur Ayam & 24853.06 & 25150 & 27750 & 22000 & 1335.16 & -0.342104 & 2.481709 & 2.146529 & 0.341891 \\
\hline Cabai Merah & 39020.41 & 37800 & 62250 & 27200 & 8097.09 & 0.866612 & 3.153869 & 2.653314 & 0.265363 \\
\hline Cabai Rawit & 44129.59 & 41100 & 77650 & 30400 & 11662.42 & 1.120055 & 3.465239 & 4.543570 & 0.103128 \\
\hline Daging Ayam & 34105.1 & 34100 & 39000 & 29250 & 2154.60 & 0.160334 & 2.671956 & 0.177359 & 0.915139 \\
\hline Daging Sapi & 117438.8 & 117900 & 125450 & 113850 & 2598.68 & 1.085407 & 4.597804 & 12.23205 & 0.002207 \\
\hline Inflasi & 2.679796 & 2.98 & 3.88 & 1.32 & 0.81 & -0.533447 & 1.818172 & 5.175584 & 0.075186 \\
\hline Gula Pasir & 14316.33 & 14200 & 18250 & 13100 & 1015.06 & 2.137162 & 8.151895 & 63.99007 & 0.000000 \\
\hline
\end{tabular}

Sumber : Analisis Data Sekunder, 2021

Uji normalitas Jarque-Bera pada Tabel 1. digunakan untuk melihat distribusi kenormalan data dengan mempertimbangkan skewness dan kurtosis. Jika nilai probability Jarque-Bera tidak signifikan atau lebih dari alpha maka variabel terdistribusi normal. Berdasarkan Tabel. nilai probability Jarque-Bera yang lebih besar dari alpha yaitu bawang merah, bawang putih, minyak goreng, telur ayam, cabai merah, cabai rawit daging ayam, dan inflasi. Variabel beras dan gula pasir memiliki nilai probability Jarque-
Bera yang signifikan. Berdasarkan Central Limit Theorem (A. Barri, 2019; Fitrianto \& Hanafi, 2014; Islam, 2018), jumlah sample data yang terus meningkat atau lebih dari 30 maka data semakin mendekati normalitas. Kondisi ini dilihat dari populasi $(\mathrm{N})$ yang tidak terbatas, standar deviasi yang terbatas, standardized mean dari sample mendekati distribusi normal dengan nilai rata-rata (mean) sama dengan nilai mean pada populasi.

Tabel 2. Uji Asumsi Klasik dan Nilai R-Squared Analisis Regresi Linier Berganda

\begin{tabular}{ll}
\hline \multicolumn{1}{c}{ Indikator } & Nilai \\
\hline R-squared & 0.867234 \\
\hline Adjusted R-squared & 0.832295 \\
\hline S.E. of regression & 0.333674 \\
\hline F-statistic & 24.82173 \\
\hline Prob(F-statistic) & 0.000000 \\
\hline Serial Correlation LM Test & \\
Prob. Chi-Square(15) & 0.169800 \\
\hline Heteroskedasticity: Breusch-Pagan-Godfrey (BPG) & \\
Prob. Chi-Square(10) & 0.866700 \\
\hline Multicolinearity:Variance Inflation Factors (VIF) & \\
Bawang Merah & 3.723515 \\
Beras & 1.589874 \\
Bawang Putih & 2.526772 \\
Cabe Merah & 2.976025 \\
Cabe Rawit & 3.901056 \\
Daging Ayam & 2.310537 \\
Daging Sapi & 2.650061 \\
Gula Pasir & 2.401376 \\
Minyak Goreng & 2.184216 \\
Telur & 2.827496 \\
\hline
\end{tabular}

Sumber: Analisis Data Sekunder, 2021

Nilai R-squared berdasarkan Tabel 2, merupakan indikator goodness of fit yang menunjukkan proporsi variasi total dalam variabel terikat yang dijelaskan oleh variabel bebas sebesar $86.72 \%$. Serial Correlation LM Test digunakan sebagai indikator autokorelasi dengan Prob Chi-Square pada lag 15 yaitu
0.169800 . Nilai Prob Chi-Square lebih besar dari alpha 0.05 maka tidak signifikan, artinya estimasi bebas dari autokorelasi. Uji hetorokedastisitas menggunakan BreuschPagan-Godfrey (BPG) menunjukkan nilai Prob. Chi-Square tidak siginifikan yaitu 0.866700 , sehingga estimasi bebas dari 
Agrisaintifika

Jurnal Ilmu-Ilmu Pertanian

Vol. 5, No. 2, 2021

Helbawanti, et al. 2021

heterokedastisitas. Nilai Variance Inflation Factors (VIF) pada seluruh variabel lebih kecil dari 10 maka estimasi tidak terdapat masalah multikolinearitas.

Tabel 3. menunjukkan pengaruh bahan pangan terhadap inflasi. Variabel bebas memiliki pengaruh signifikan jika nilai Prob. lebih kecil dari nilai signifikansi alpha yang digunakan Variabel bahan pangan yang berpengaruh signifikan yaitu bawang merah, beras, bawang putih, daging ayam, daging sapi, gula pasir, dan minyak goreng. Bahan pangan bawang putih, daging ayam, dan gula pasir berpengaruh positif terhadap inflasi. Kenaikan harga bawang putih, daging ayam, dan dan gula pasir sebesar $1 \%$ akan meningkatkan inflasi. Koefisien bahan pangan bawang merah, beras, daging sapi, dan minyak goreng bertanda negatif maka pengaruh pada kenaikan inflasi lebih lambat dibanding bahan pangan lain yang berpengaruh signifikan.

Daging ayam berperan cukup besar terhadap kenaikan inflasi. Stok daging ayam menipis dan kebijakan culling dan cutting mulai Agustus 2020, sehingga harga daging ayam cenderung meningkat. Kenaikan harga daging ayam dapat dipicu biaya produksi yang meningkat akibat kenaikan harga pakan dan kenaikan harga biji-bijian di tingkat global. Keterlambatan impor bawang putih akibat terbatasnya armada kapal yang dari Tiongkok ke Indonesia (TPIP, 2020). Bawang putih merupakan komoditi yang penting dalam pengolahan pangan skala rumah tangga maupun industri. Selain itu, budidaya bawang putih cukup sulit karena rentan hama dan penyakit serta kesesuaian topografi wilayah tertentu untuk budiaya. Permintaan bawang putih tidak terpenuhi dari ketersediaan domestik menyebabkan harga terus meningkat. Harga gula pasir bergerak naik, sehingga kenaikan $1 \%$ dapat menyebabkan kenaikan inflasi 2,22\%. Konsumsi gula pasir dalam kategori tinggi, sehingga harga gula pasir masih di atas Harga Eceran Tertinggi (HET) sepanjang tahun 2020 (Kemendag, 2020).

Fluktuasi harga komoditi dapat berkontribusi pada inflasi karena ketidakpastian harga akan mengganggu perkiraan harga (future price) dan kondisi permintaan dan penawaran (Moreira, 2014). Menurut (De Gregorio, 2012), bahan pangan memiliki proporsi yang lebih besar dibanding kebutuhan non-pangan dari total pengeluaran rumah tangga. Dengan demikian jika terjadi perubahan harga maka akan mempengaruhi nilai upah riil rumah tangga yang dapat dibelanjakan. Permasalahan harga pangan berdasarkan penelitian (Tule et al., 2019), menjadi variabel yang dapat menganalisis perkiraan inflasi dari variasi perubahan harga bahan pangan. Selain itu, penggunaan tenaga kerja yang banyak pada sektor pertanian dapat menjadi salah satu penyebab kenaikan tingkat upah, sehingga biaya faktor produksi meningkat yang merupakan cost-pull inflation.

Trend harga bawang merah, beras, daging sapi, dan minyak goreng cenderung meningkat dari tahun 2017 sampai tahun Juli 2021. Berdasarkan Kementerian Keuangan, tahun 2017 inflasi volatile food tergolong rendah yaitu $0,71 \%$ (yoy) dan sumber deflasi dari bahan pangan bawang merah, beras, daging sapi, dan minyak goreng mencapai $0,53 \%(\mathrm{mtm})$. Harga bawan merah turun dari Rp5000,- menjadi Rp4000,- menyebabkan deflasi $-2.66 \%$ pada tahun 2017, sedangkan beras dan daging sapi mengalami inflasi rendah. Harga komoditi turun disebabkan pasokan melimpah saat panen di sentra produksi dan kebijakan pemerintah seperti operasi pasar dan Cadangan Beras Pemerintah (CBP) (TPIP, 2017, 2018). Harga beras terkendali karena pemerintah melakukan intervensi pada harga eceran tertinggi (ceiling price) dan harga dasar (floor price). Pergerakan harga komoditi di tingkat global dapat mempengaruhi harga komoditi domestik, sehingga berdampak pada inflasi. Pada tahun 2019, komoditi global mengalami perlambatan yaitu pada CPO dan daging sapi (TPIP, 2019). Permintaan minyak goreng semakin menurun seiring pemberlakukan pembatasan aktivitas (PSBB) selalam pandemi Covid-19. Pengaruh PSBB pada sistem agribisnis CPO yaitu pengurangan tenaga kerja di lahan perkebunan kelapa sawit. Dengan demikian, kontribusi 
Helbawanti, et al. 2021

perubahan harga minyak goreng dan daging

sapi terhadap inflasi cenderung rendah.

Tabel 3. Pengaruh Variabel Harga Bahan Pangan terhadap Inflasi

\begin{tabular}{|c|c|c|c|c|}
\hline Variable & Coefficient & Std. Error & t-Statistic & Prob. \\
\hline C & 343.7539 & 53.15626 & 6.466857 & 0.0000 \\
\hline Bawang Merah & -1.939415 & 0.484072 & -4.006460 & $0.0003^{* \star *}$ \\
\hline Beras & -13.20707 & 3.992175 & -3.308238 & $0.0021^{* * *}$ \\
\hline Bawang Putih & 2.067060 & 0.395869 & 5.221576 & $0.0000^{* * *}$ \\
\hline Cabe Merah & 0.103813 & 0.420643 & 0.246795 & 0.8064 \\
\hline Cabe Rawit & 0.000733 & 0.391952 & 0.001870 & 0.9985 \\
\hline Daging Ayam & 3.670161 & 1.159637 & 3.164924 & $0.0031^{* * *}$ \\
\hline Daging Sapi & -17.40756 & 3.582685 & -4.858803 & $0.0000^{* * *}$ \\
\hline Gula Pasir & 2.221698 & 1.122525 & 1.979197 & $0.0551^{*}$ \\
\hline Minyak Goreng & -5.683519 & 1.710139 & -3.323425 & $0.0020^{* * *}$ \\
\hline Telur Ayam & -2.154620 & 1.489631 & -1.446412 & 0.1563 \\
\hline
\end{tabular}

Sumber : Analisis Data Sekunder, 2021

\section{SIMPULAN}

Inflasi merupakan salah satu indikator yang penting untuk mengevaluasi kondisi perekonomian. Bahan pangan yang tergolong volatile food dapat berkontribusi pada pergerakan inflasi nasional karena mengalami fluktuasi harga. Penyebab fluktuasi harga bahan pangan antara lain supply pada saat masa panen, cuaca, tingkat permintaan, harga bahan baku, dan harga di tingkat internasional. Pada masa pandemi Covid-19, ketersediaan bahan pangan dapat dipengaruhi kebijakan pembatasan aktivitas atau mobilitas. Bawang merah, beras, daging sapi, dan minyak goreng memberikan pengaruh negatif pada inflasi, karena cenderung terjadi deflasi pada pergerakan harga bahan pangan tersebut. Penurunan daya beli turut memicu inflasi yang rendah seiring berjalannya pengaruh Covid-19 terhadap perekonomian. Bawang putih, daging ayam, dan gula pasir berpengaruh positif pada peningkatan inflasi karena memiliki trend pergerakan harga yang meningkat dari tahun 2017-2021 dan merupakan bahan pangan dengan konsumsi yang cukup tinggi dalam konsumsi rumah tangga.

\section{DAFTAR PUSTAKA}

A. Barri, M. (2019). A Simulation Showing the Role of Central Limit Theorem in Handling Non-Normal Distributions. $\begin{array}{lcr}\text { American Journal of } & \text { Educational } \\ \text { Research, } & 7(8), & 591-598 . \\ \text { https://doi.org/10.12691/education-7-8-8 }\end{array}$

Al-Shawarby, S., \& Selim, H. (2013). Are International Food Price Spikes the Source of Egypt's High Inflation. Financial and Monetary Policy Studies, 36(2013), 61-81. http://link.springer.com/10.1007/978-3642-35697-1

Auer, R. A., \& Mehrotra, A. (2014). Trade Linkages and The Globalisation of Inflation in Asia and The Pacific. Journal of International Money and Finance, 49(2014), 129-151. https://doi.org/10.1016/j.jimonfin.2014.0 5.008

Bandara, J. S. (2013). What is Driving India's Food Inflation? A Survey of Recent Evidence. South Asia Economic Journal, 14(1), 127-156. https://doi.org/10.1177/13915614134779 44

Bhattacharya, R., \& Jain, R. (2019). Can monetary policy stabilise food inflation? Evidence from advanced and emerging economies. Economic Modelling, 89(2019), 122-141. https://doi.org/10.1016/j.econmod.2019. 10.005

Bhattacharya, R., \& Sen Gupta, A. (2017). Drivers and Impact of Food Inflation in India. Macroeconomics and Finance in 
Agrisaintifika

Jurnal Ilmu-Ilmu Pertanian

Vol. 5, No. 2, 2021

Helbawanti, et al. 2021

Emerging Market Economies, 11(2), 146-168.

https://doi.org/10.1080/17520843.2017.1 351461

Boediono. (2005). Ekonomi Makro. PBFE Yogyakarta.

BPS. (2021). Data Kependudukan Semester I Tahun 2021. Badan Pusat Statistik, 1.

Breusch, T. S., \& Pagan, A. R. (1980). The Lagrange Multiplier Test and its Applications to Model Specification in Econometrics. The Review of Economic Studies, 47(1), 239-253. https://doi.org/10.2307/2297111

Darma, D. C., Pusriadi, T., \& Permadi, H. Y. (2018). Dampak Kenaikan Harga Komoditas Sembako terhadap Tingkat Inflasi di Indonesia (Manajemen, Akuntansi, Dan Perbankkan 2018).

De Gregorio, J. (2012). Commodity prices, monetary policy, and inflation. IMF Economic Review, 60(4), 600-633. https://doi.org/10.1057/imfer.2012.15

Fitrianto, A., \& Hanafi, I. (2014). Exploring central limit theorem on world population density data. AIP Conference Proceedings, 1635, 737-741. https://doi.org/10.1063/1.4903664

Holtemöller, O., \& Mallick, S. (2016). Global food prices and monetary policy in an emerging market economy: The case of India. Journal of Asian Economics, 46(2016), $\quad$ 56-70. https://doi.org/10.1016/j.asieco.2016.08. 005

Iddrisu, A. A., \& Alagidede, I. P. (2020). Monetary policy and food inflation in South Africa: A quantile regression analysis. Food Policy, 91(2020), 1-13. https://doi.org/10.1016/j.foodpol.2019.10 1816

Islam, M. R. (2018). Sample Size and Its Role in Central Limit Theorem (CLT). International Journal of Physics and Mathematics, 4(1), 1-7. https://doi.org/10.31295/pm.v1n1.42

Kemendag. (2020). Analisis Perkembangan Harga Bahan Pangan Pokok di Pasar Domestik dan Internasional. In Pusat Pengkajian Perdagangan Dalam Negeri. https://doi.org/10.1016/j.ajodo.2020.09.0
06

Kementerian PPN/Bappenas. (2020). Laporan Perkembangan Ekonomi Indonesia dan Dunia Triwulan III Tahun 2020. In R. H. Maulida (Ed.), Kementerian PPN/Bappenas (III/2020, Vol. 4, Issue 3). Kedeputian Bidang Ekonomi Kementerian PPN/Bappenas.

Mija, S., Slobozian, D., Cuhal, R., \& Stratan, A. (2013). How Core Inflation Reacts to The Second Round Effects. Romanian Journal of Economic Forecasting, 16(1), 98-118.

Moreira, R. R. (2014). Commodities Prices Volatility, Expected Inflation and GDP Levels: An Application for a Netexporting Economy. Procedia Economics and Finance, 14(2014), 435-444. https://doi.org/10.1016/s22125671(14)00732-1

TPIP. (2017). Release Note Inflasi Desember 2017 (Issue Desember).

TPIP. (2018). Analisis Inflasi Desember 2018 Tim Pengendalian Inflasi Pusat (TPIP).

TPIP. (2019). Analisis Inflasi Desember 2019 Tim Pengendalian Inflasi Pusat (TPIP).

TPIP. (2020). Analisis Inflasi Desember 2020 Tim Pengendalian Inflasi Pusat (TPIP) (Issue Desember).

Tule, M. K., Salisu, A. A., \& Chiemeke, C. C. (2019). Can agricultural Commodity Prices Predict Nigeria's Inflation? Journal of Commodity Markets, 16(2019), 1-21. https://doi.org/10.1016/j.jcomm.2019.02. 002

Widiarsih, D. (2012). Pengaruh Sektor Komoditi Beras Terhadap Inflasi Bahan Makanan. Jurnal Sosial Ekonomi Pembangunan, 2(6), 244-256. https://ejournal.unri.ac.id/index.php/JSE P/article/view/863 